\title{
Detection of Changes in Surface Water Bodies Urban Area with NDWI and MNDWI Methods
}

\author{
Muhammad Ichsan Ali ${ }^{\# *}$, Gufran Darma Dirawan", Abdul Hafid Hasim, Muh. Rais Abidin ${ }^{+}$

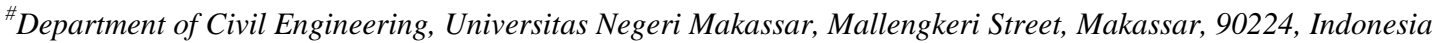 \\ E-mail: *m.ichsan.ali@unm.ac.id; gufrandarma@unm.ac.id; abdulhafidhasim@gmail.com \\ ${ }^{+}$Department of Geography, Universitas Negeri Makassar, Mallengkeri Street, Makassar, 90224, Indonesia \\ E-mail: m.rais@unm.ac.id
}

\begin{abstract}
Land surface water bodies, an essential part of the Earth's water cycle such as rivers, lakes, swamp, and reservoirs, influence the global ecosystem and climate global significantly. Makassar, one of the most populated cities in Indonesia, recently experiences massive development that affects the existence of vegetation area and urban aquatic ecosystem. This study attempts to detect the urban surface water bodies and to monitor the change by using Landsat OLI TIRS. In order to extract the high accuracy of data, the image data utilized in this study was acquired by Landsat 8 OLI TIRS sensor on 14 December 2000, 27 December 2009 and 06 January 2019 from the United States Geological Survey (USGS) portal analyzed by Normalized Difference Water Index (NDWI) and Modified Normalized Difference Water Index (MNDWI). These methods are scientifically used to classify the data into two categories consisted of water and non-water objects. The result shows that in the last nine years, urban surface water bodies increased around 129.8 ha distributed mostly in Manggala area. Due to rapid urban development such as housing, makes the urban runoff concentrating in low land and creates giant swamp as well as an urban wetland. In coastal areas however decline of the water body due to dominantly by massive reclamation, housing and factory settlement. The increase of urban surface water bodies can lower the urban heat while massive development in the built-up area can worsen the urban heat.
\end{abstract}

Keywords - Landsat OLI TIRS; urban water bodies; water index; urban heat.

\section{INTRODUCTION}

Land Use and Land Cover (LU/LC) changes are essential to study to reach the concept of sustainable development [1] successfully. As a necessary part of the earth's water cycle, urban aquatic ecosystem such as reservoirs, rivers and lakes, water is an integral component of the ecosystem which plays a significant role to influence climate system and global ecosystem. Therefore, understanding managing water resources and by monitoring and analyses the hydrology process of the urban aquatic ecosystem and mapping their spatial distribution is essential [2]-[4] since monitoring the change of surface water and delivering the information on the dynamics of surface water body can be used as a decision-making process and policy [5]. Moreover, the destruction and decline of urban surface water bodies caused by rapid urbanization [6] and increased agricultural development [7] which significantly affect regional climate, living environment, public health and urban heat island [8]. Also by using remote sensing data with Geographic Information System (GIS) to monitor and measure the change of urban surface water bodies is essential because it can be utilized in automatic or semi-automatic water body extraction and mapping [9]. The data include the images which can be obtained by Advanced Space borne Thermal Emission and Reflection Radiometer (ASTER) [10], [11], the Landsat series [12]-[14] and Sentinel-2 multispectral imagery [6], [15].

Analysis of the concentration of flow in a river system is critical to detect the causes of flooding [16]. Besides that, the level of drainage density, drainage patterns and the shape of the watershed is also an essential factor in influencing the flow hydrograph, fast or slow the amount of water flow from the surface of the land to bring to the river channel [17]. By using GIS modeling the cause of the occurrence is expected to be analyzed more clearly. In terms of space, there are related elements which are responses from the rain in a topographic zone. Elements such as runoff flow, soil erosion, sediment buildup all strongly influenced by existing land use in the area. Settlements that populate the area affect the optimization of watershed function so that it can cause adverse impacts on the region [18].

The use of the hydrological model is considered very important in making analysis and solutions to a problem 
with an integrated geographical approach [19]. Geographic Information System (GIS) is an efficient tool in collecting primary data, processing, and analysis, and presenting spatial data, as well as assessments of water resources with the right, fast and integrated spatial technology objectives compared to the mapping of groundwater potential which is at depth using Geoelectric as an imaging device [20]-[22].

Mapping and monitoring urban surface water bodies with high extraction accuracy have been widely used such as in reservoirs [23], rivers [23], [24], lakes [23], [25], coastline [26] and water bodies in an urban area. However, due to the mixed background and heterogeneous scenes, mapping urban surface water must deal with the dramatic overestimation phenomenon [11]. Many studies have suggested the use of water index to extract the surface water bodies from remotely sensed data. It could enhance the difference between water and non-water areas based on combinations of two or more spectral bands by utilizing various algebraic operations. For instance, the use of the combination of the Normalized Difference Water Index (NDWI), Modified NDWI (MNDWI) and Automated Water Extraction Index (AWEI) could extract the water body and change detection in Lake Burdur [25]. The Normalized Difference Water Index (NDWI) is subject to excerpt water features from Landsat TM using band 2 and band 4 [27]. NDWI also makes the classification of potential water bodies using Landsat 8 OLI and a combination of two boosted random forest classifiers [23]. NDWI introduces the Automated Water Extraction Index (AWEI) to improve water extraction accuracy in areas that include shadows and dark surfaces [28]. Meanwhile, the research revealed that NDWI has a better result for deeper and worse for shallower parts of the water surface. Therefore, the use of the normalized difference water index (NDWI) approach increases the reflectance properties of water by reducing the low reflectance of Near Infrared (NIR) and enhancing the reflectance in green wavelength [27], [29].

The fact that Makassar as one of the biggest city in the eastern part of Indonesia has been undergoing rapid increased in urbanization such as residence, shopping mall, housing, transportation, and educational facilities, parking area as well as governmental building influence the decline of urban surface water bodies. The objective of this study is to detect the change in urban surface water bodies by using water indices extracted from Landsat OLI 8 TIRS in different periods.

\section{MATERIALS AND MethodS}

\section{A. Study Area}

Geographically, Makassar City is located on the coast of the West Coast in the southern part of South Sulawesi, at the coordinates of $119^{\circ}, 18^{\prime}, 27^{\prime}, 97^{\prime \prime}$ East Longitude and 5'. 8', 6', 19 ' South Latitude with an area of $175.77 \mathrm{~km}^{2}$ covering 14 sub-districts. Administratively, Makassar City has regional boundaries, namely the South, bordering Gowa Regency, the north bordering the Pangkajene Kepulauan Regency, the east bordering the Maros Regency and the west side adjoining the Makassar Strait. The topography is generally a coastal area. The height of Makassar City ranges from 0.5 to 10 meters above sea level. Makassar City is a city that located near the coast, stretching along the West and North corridors, commonly known as a city with the characteristic "Waterfront City," inside it flows several rivers which all come into the town (Tallo River, Jeneberang, Pampang). For example, Sunga Jeneberang which flows across the territory of Gowa Regency and empties into the southern part of Makassar City is a medium capacity river (1-2 m / s). Whereas the Tallo and Pampang rivers which drain into the northern part of Makassar are rivers with low capacity debited approximately only reaching $0-5 \mathrm{~m} / \mathrm{sec}$ in the dry season.

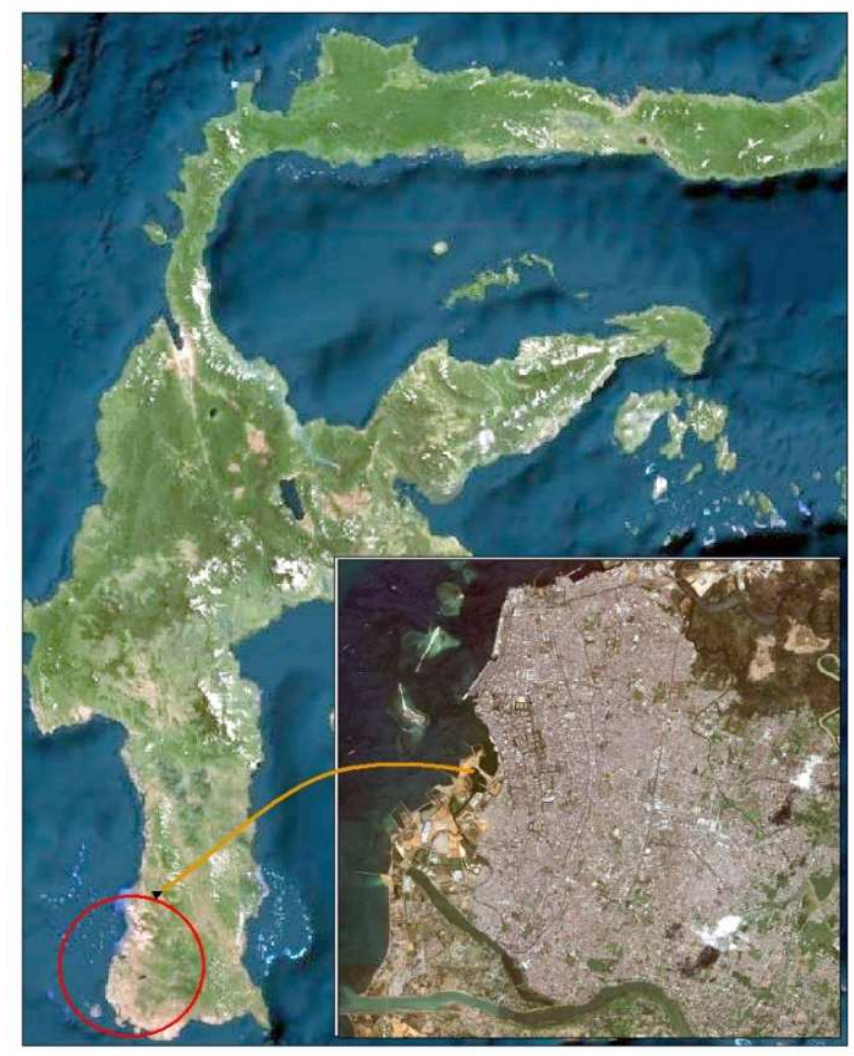

Fig. 1 Study Area (Makassar)

\section{B. Methods}

The image data that utilized in this study was acquired by Landsat 8 OLI TIRS sensor on 14 December 2000, 27 December 2009 and 06 January 2019 from the United States Geological Survey (USGS) portal (Table 1).

TABLE I

LANDSAT 8 OLI BANDS

\begin{tabular}{|c|c|c|}
\hline Band Name & $\begin{array}{c}\text { Wavelength } \\
(\boldsymbol{\mu m})\end{array}$ & $\begin{array}{c}\text { Resolution } \\
(\mathbf{m})\end{array}$ \\
\hline Deep blue & $0.435-0.451$ & \multirow{2}{*}{30} \\
\hline Blue & $0.452-0.512$ & \\
\hline Green & $0.533-0.590$ & \multirow{2}{*}{30} \\
\hline Red & $0.636-0.673$ & \\
\hline Near Infrared (NIR) & $0.851-0.879$ & \\
\hline $\begin{array}{c}\text { Short-wave Infrared 1 } \\
\text { (SWIR_1) }\end{array}$ & $1.566-1.651$ & \\
\cline { 1 - 2 } $\begin{array}{c}\text { Short-wave Infrared 2 } \\
\text { (SWIR_2) }\end{array}$ & $2.107-2.294$ & \\
\hline
\end{tabular}

To extract the image data, spectral water index has been used to extract the urban surface water bodies from remotely 
sensed data by calculating the difference between two image bands and applying an appropriate threshold to segment the results into two categories (water and non-water features). Among 11 bends, five bands were utilized in recent method consisted of blue (0.45-0.52), green $(0.52-0.60)$, red (0.63$0.69)$, near infrared (NIR-0.76-0-90) and short wave infrared (SWIR-1.55-1.75).

Table 2 shows that this study applies the Normalized Difference Water Index (NDWI) because it was first suggested by Mcfeeters [27], to detect surface waters in wetland environments and measure surface water dimensions, but NDWI is not able to extract shallow part of water surface and differentiate built-up area from water objects [29]. Also, to enhance the level of accuracy of the result, it should use the summation of NDWI and a modified NDWI namely MNDWI), where the equation between NDWI and MNDWI are:
TABLE II

MULTIBAND INDEXES

\begin{tabular}{|c|c|c|c|}
\hline $\begin{array}{c}\text { Multiband } \\
\text { Index }\end{array}$ & Equation & Remark & Reference \\
\hline $\begin{array}{c}\text { Normalized } \\
\text { Difference } \\
\text { Water Index }\end{array}$ & $\begin{array}{c}\text { NDWI = Green- } \\
\text { NIR }) /(\text { Green+NIR })\end{array}$ & $\begin{array}{c}\text { Water } \\
\text { has } \\
\text { positive } \\
\text { value }\end{array}$ & {$[27]$} \\
\hline $\begin{array}{c}\text { Modified } \\
\text { Normalized } \\
\text { Difference } \\
\text { Water Index }\end{array}$ & $\begin{array}{c}\text { MNDWI = (Green- } \\
\text { SWIR_1)/(Green+S }\end{array}$ & $\begin{array}{c}\text { Water } \\
\text { has } \\
\text { positive } \\
\text { value }\end{array}$ & {$[29]$} \\
\hline
\end{tabular}

As a result, water features have positive values and are enhanced. Vegetation and soil features generally related to zero or negative values and is suppressed [27].

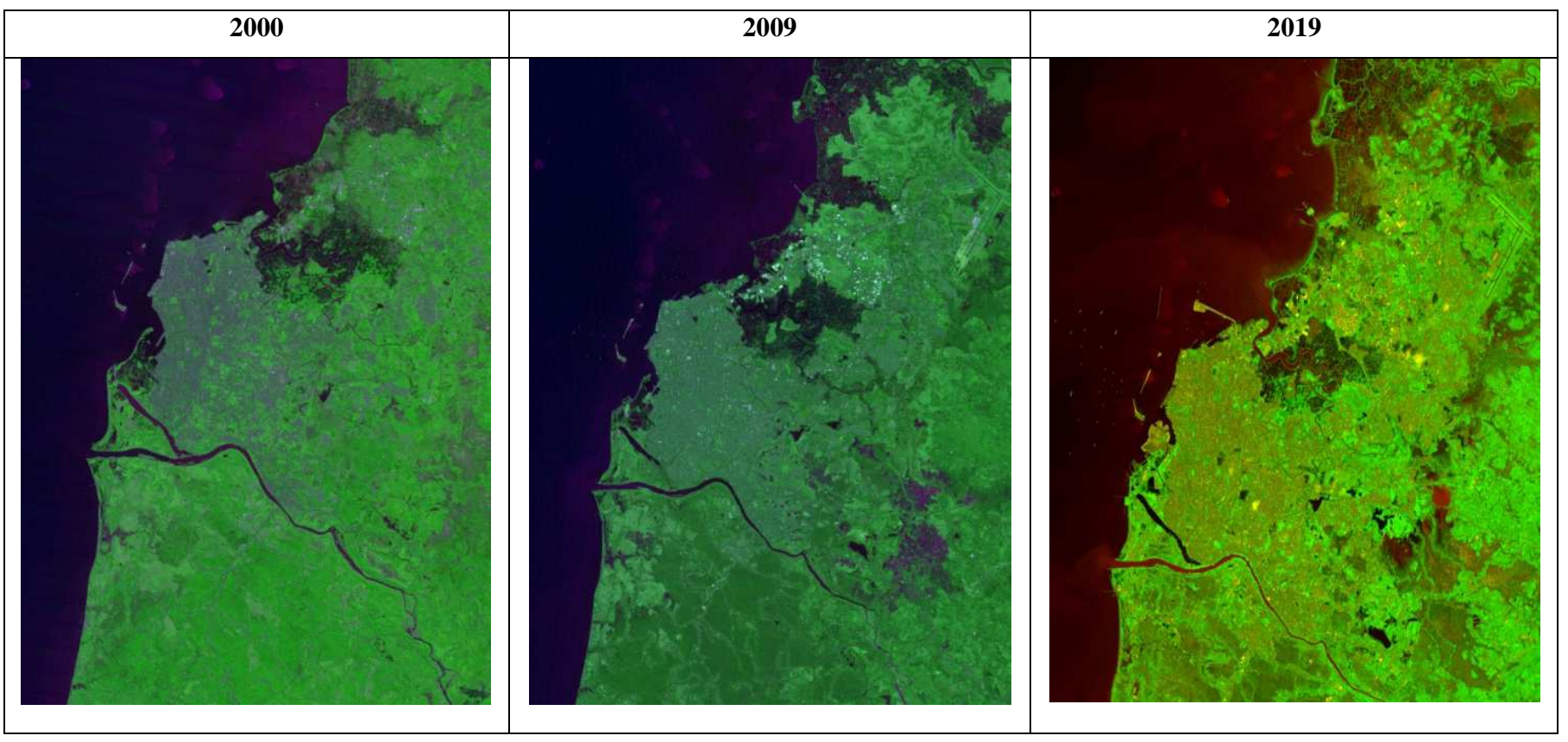

Fig. 2 Landsat 8 OLI showing Major Water Surface of Makassar

By using Landsat 8 as shown in Figure 2, there is an apparent change in surface water from 2000 to 2019. Availability of Landsat 8 image data covering all regions and with spatial, temporal, and spectral resolutions are the three advantages possessed by these images, so it is beneficial for natural resource management, and one of them is in the area of coastal and marine areas.

Applications that can be applied using Landsat 8 data include coastline identification, mangrove forest identification, identification of coral reef and sea grass ecosystems, extraction of bathymetry information and retrieval of water quality information including chlorophyll, sea surface temperature (SPL) and suspended solids (MPT). In general, the use of remote sensing data for applications in the coastal and marine areas mentioned above can be divided into two parts according to the characteristics of electromagnetic waves, namely to study objects in the water column and above the water column.

\section{RESULT AND DISCUSSION}

\section{A. Normalized Difference Water Index (NDWI)}

The urban surface water bodies were extracted by Normalized Difference Water Index (NDWI) from Landsat satellite. The images were then classified into two categories consisted of water and non-water objects. Furthermore, water areas have values greater than zero while vegetation and urban area have negative values [27]. Table 3 shows changes in urban surface water bodies during nine years in urban surface water bodies of Makassar city from 2000 to 2019. The result of the Normalized Difference Water Index (NDWI) reveals that the urban surface water bodies of Makassar have been experiencing an increase from 2000 to 2019. In 2000, the area of the urban aquatic ecosystem was 1162 ha while in 2009 increased to 1233.9 ha, and 2019 reaches 1291.8 ha. 
TABLE III

THE Changes on URBAN SURFACE WATER BodIES WITH NORMALIZED DIFFERENCE WATER INDEX (NDWI)

\begin{tabular}{|c|c|c|}
\hline No. & Years & Urban Surface Water Bodies (Ha) \\
\hline 1 & 2019 & $1,162.00$ \\
\hline 2 & 2009 & $1,233.90$ \\
\hline 3 & 2000 & $1,291.80$ \\
\hline
\end{tabular}

Table 3 above shows that during the last nine years, more than 129.8 ha area of urban surface water bodies increased while the distribution of urban surface water bodies in Makassar based on NDWI analysis.

Figure 3 below shows that in 2000, mostly the water bodies distributed in Tamalate, Tamalanrea and Biringkanaya District. In 2009, urban aquatic ecosystem spread dominantly in Tamalate, Tamalanrea, and Biringkanaya while Manggala district appeared as a new area of the existence of urban surface water body, and finally, in 2019, the urban water areas disseminate mostly in Tamalate, Tamalanrea, Biringkanaya, and Manggala District.



Fig. 3 Normalized Difference Water Index (NDWI)

\section{B. Modified Normalized Difference Water Index (MNDWI)}

Table 4 shows changes in urban surface water bodies during nine years in urban surface water bodies of Makassar city from 2000 to 2019.

TABLE IV

The Changes on Urban Surface Water Bodies With Modified NORMALIZED DIFFERENCE WATER INDEX (MNDWI).

\begin{tabular}{|c|c|c|}
\hline No. & Years & Urban Surface Water Bodies (Ha) \\
\hline 1 & 2019 & 1,400 \\
\hline 2 & 2009 & 1,377 \\
\hline 3 & 2000 & 1,547 \\
\hline
\end{tabular}

The urban water body was extracted by Modified Normalized Difference Water Body because this method more suitable for increasing the accuracy of water extraction and effectively reduce as well as remove built-up land noise than NDWI. Furthermore, MNDWI can be concluded more detail detecting urban water surface than NDWI [29].

The result of Modified Normalized Difference Water Index (MNDWI) shows that the urban surface water bodies of Makassar have been experiencing fluctuation from 2000 to 2019. In 2000, the area of the urban aquatic ecosystem was 1547 ha while in 2009 went down to 1377 ha, and 2019 reaches 1400 ha. The distribution of urban surface water bodies in Makassar based on MNDWI analysis can be seen in following figure 4.

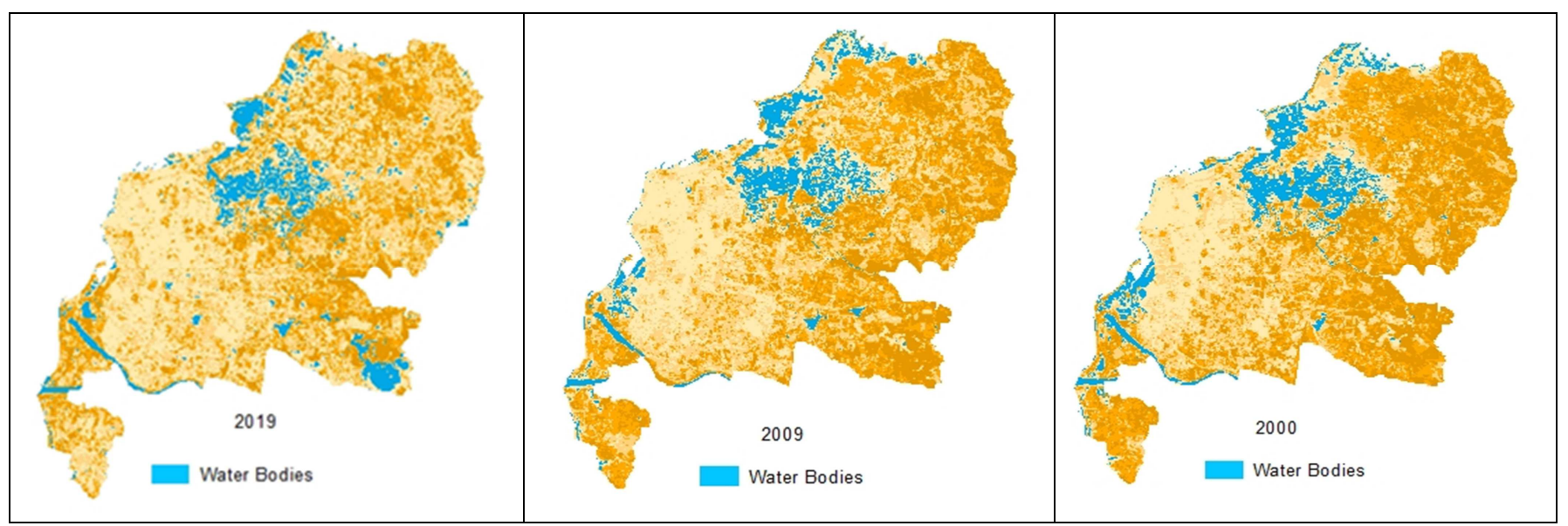

Fig. 4 Modified Normalized Difference Water Index (MNDWI) 


\section{Comparison NDWI and MNDWI}

MNDWI was modified from NDWI to find the best method to detect the water body. Xu stated that Modified Normalized Difference Water Body is a more suitable method for increasing the accuracy of water extraction and effectively reduce as well as remove built-up land noise than NDWI [29]. The different result of MNDWI and NDWI can be seen in the following Table 5 .

TABLE V

THE COMPARISON OF MNDWI AND NDWI

\begin{tabular}{|c|c|c|c|}
\hline No. & Years & MNDWI (Ha) & NDWI (Ha) \\
\hline 1 & 2019 & $1,400.00$ & $1,162.00$ \\
\hline 2 & 2009 & $1,377.00$ & $1,233.90$ \\
\hline 3 & 2000 & $1,547.00$ & $1,291.80$ \\
\hline
\end{tabular}

NMDWI and NDWI are the most accurate methods to detect, measure and monitor the urban surface water bodies because they can agglomerate into two classes consisted of water and non-water areas. The result of NDWI shows that in the last nine years, the urban aquatic ecosystem in Makassar has been increasing more than 129.8 ha. However, the significant increase only happens in Manggala District while other Districts are experiencing a decline. Manggala District especially experiences an increase of water bodies due to massive urban development such as housing and residence in which many agricultural areas such as rice field and swamps are converted. As a result, the urban wetland is getting wider because the urban runoff concentrated in some regions deficient land and created giant urban wetland so that in 2000, the urban wetland was smaller while in 2009 and 2019 are getting wider in Manggala District. Besides, water bodies in Tamalate, Tamalanrea and Biringkanaya District, especially in coastal areas, decreased due to urban development such as massive reclamation in Losari Beach, housing and factory while either water bodies, agricultural or vegetation area are mostly converted to be built-up areas [30].

Furthermore, an increase of land use and land cover change especially the conversion of water bodies can trigger phenomena of urban heat island and urban temperatures getting worse [31]-[33] while urban surface water bodies can lower the temperature especially Land Surface Temperature (LST) [34]. Also, rapid development can also lead to a decrease in the quality of freshwater [35]. Therefore, in urban planning policy, the local government has to tighten the regulation not to allow either local societies or developers to build house or resident.

The NDWI approach is effective for the detection of surface water changes, especially in detecting differences between two and three different times, simultaneously [36]. The MNDWI method can suppress information about land built effectively by highlighting water information and accurately extracting information from water bodies in the study area. While details on increasing water use, NDWI is always mixed with noise from the land built and the city of water bodies extracted according to the index is overestimated. Therefore, NDWI is inadequate to improve and retrieve information about water in areas dominated by the land under construction [37]. This shows that MNDWI can significantly improve information about water, especially in built-up areas.

Interpretation of satellite imagery cannot indeed be used to describe the existence of aquifers directly, but in the initial investigation (estimation) to find out the existence of aquifers in the image can be used to determine groundwater reserves. Indicators to detect the presence of groundwater are such as soil moisture anomalies, vegetation density, and natural drainage conditions [38]. In India, the use of Landsat satellite imagery used as the primary data source in groundwater surveys, and the results prove that underground information from pumping tests has to do with indicators of groundwater obtained from satellite images [39].

The results [40], show that MNDWI can improve water bodies and suppress built-up capabilities more efficiently than NDWI. Also, the $10 \mathrm{~m}$ MNDWI produced by four panoramic sharpness algorithms can represent more detailed spatial information from the $20 \mathrm{~m}$ MNDWI water body generated from the original image. Therefore, MNDWI at 10 $\mathrm{m}$ resolution can extract maps of water bodies that are more accurate than 10-m NDWI and 20-m MNDWI. No definite relationship is needed to improve accuracy.

\section{CONCLUSIONS}

Normalized Difference Water Index (NDWI) and Modified Normalized Difference Water Index (MNDWI) are the best methods to categorize the water bodies from other objects. During nine years, the urban aquatic ecosystem in Makassar has been increasing. The increase however only happens in Manggala District because massive urban development makes the agricultural area and swamp getting smaller so that the urban runoff concentrates in low land and create a large urban wetland. Meanwhile, in a coastal area like Tamalate, Tamalanrea, and Biringkanaya, the urban surface water bodies decline due to construction activities such as massive reclamation, housing, and factories.

\section{REFERENCES}

[1] I. R. Hegazy and M. R. Kaloop, "Monitoring urban growth and land use change detection with GIS and remote sensing techniques in Daqahlia governorate Egypt," Int. J. Sustain. Built Environ. vol. 4, no. 1, pp. 117-124, 2015.

[2] C. J. Vorosmarty, "The storage and aging of continental runoff in large reservoir systems of the world," Ambio, vol. 26, pp. 210-219, 1997.

[3] F. Papa, C. Prigent, and W. B. Rossow, "Monitoring flood and discharge variations in the large Siberian rivers from a multi-satellite technique," Surv. Geophys., vol. 29, no. 4-5, pp. 297-317, 2008.

[4] N. Roberts, M. Taieb, P. Barker, B. Damnati, M. Icole, and D. Williamson, "Timing of the Younger Dryas event in East Africa from lake-level changes," Nature, vol. 366, no. 6451, p. 146, 1993.

[5] C. Giardino, M. Bresciani, P. Villa, and A. Martinelli, "Application of remote sensing in water resource management: the case study of Lake Trasimeno, Italy," Water Resour. Manag., vol. 24, no. 14, pp. 3885-3899, 2010.

[6] Y. Du, Y. Zhang, F. Ling, Q. Wang, W. Li, and X. Li, "Water bodies' mapping from Sentinel-2 imagery with modified normalized difference water index at $10-\mathrm{m}$ spatial resolution produced by sharpening the SWIR band," Remote Sens., vol. 8, no. 4, p. 354, 2016.

[7] B. Haack, "Monitoring wetland changes with remote sensing: an East African example," Environ. Manage., vol. 20, no. 3, pp. 411-419, 1996.

[8] P. Gober et al., "Using watered landscapes to manipulate urban heat island effects: how much water will it take to cool Phoenix?," J. Am. Plan. Assoc., vol. 76, no. 1, pp. 109-121, 2009. 
[9] H. Frey, C. Huggel, F. Paul, and W. Haeberli, "Automated detection of glacier lakes based on remote sensing in view of assessing associated hazard potentials," Grazer Schriften der Geogr. und Raumforsch., vol. 45, pp. 261-272, 2010.

[10] R. Sivanpillai and S. N. Miller, "Improvements in mapping water bodies using ASTER data," Ecol. Inform., vol. 5, no. 1, pp. 73-78, 2010.

[11] Y. Zhou, J. Luo, Z. Shen, X. Hu, and H. Yang, "Multiscale water body extraction in urban environments from satellite images," IEEE J. Sel. Top. Appl. earth Obs. Remote Sens., vol. 7, no. 10, pp. 43014312, 2014

[12] K. Singh, M. Ghosh, and S. R. Sharma, "WSB-DA: water surface boundary detection algorithm using Landsat 8 OLI data," IEEE J. Sel. Top. Appl. Earth Obs. Remote Sens., vol. 9, no. 1, pp. 363-368, 2016.

[13] M. G. Tulbure and M. Broich, "Spatiotemporal dynamic of surface water bodies using Landsat time-series data from 1999 to 2011," ISPRS J. Photogramm. Remote Sens., vol. 79, pp. 44-52, 2013.

[14] T. Acharya, D. Lee, I. Yang, and J. Lee, "Identification of water bodies in a Landsat 8 OLI image using a J48 decision tree," Sensors, vol. 16, no. 7, p. 1075, 2016.

[15] X. Yang, S. Zhao, X. Qin, N. Zhao, and L. Liang, "Mapping of urban surface water bodies from Sentinel-2 MSI imagery at $10 \mathrm{~m}$ resolution via NDWI-based image sharpening," Remote Sens., vol. 9, no. 6, p. 596, 2017.

[16] M. I. Ali, "Detection of Potential Areas to Prone Flood in Luwu Utara Regency, Indonesia," Int. J. Sci. Res., vol. 6, no. 8, pp. 14041407, 2017.

[17] Q. Weng, "Modeling urban growth effects on surface runoff with the integration of remote sensing and GIS," Environ. Manage., vol. 28, no. 6, pp. 737-748, 2001.

[18] A. Prasena and D. B. P. Shrestha, "Assessing the Effects of Land Use Change On Runoff in Bedog Sub Watershed Yogyakarta," Indonesia. J. Geogr., vol. 45, no. 1, 2013.

[19] C. Xiuwan, "Using remote sensing and GIS to analyze land cover change and its impacts on regional sustainable development," Int. J. Remote Sens., vol. 23, no. 1, pp. 107-124, 2002.

[20] M. I. Ali and M. R. Abidin, "Spatial Pattern of Crime with Geographic Information System (GIS) in Makassar, Indonesia," Int. J. Sci. Res., vol. 7, no. 4, pp. 451-457, 2018.

[21] A. J. Patandean and A. H. Hasim, "Geophysical Exploration in Hot Springs Region Soppeng Regency, Indonesia," J. Ser. J. Phys. Conf. Ser., vol. 1028, 2018.

[22] M. I. Ali and M. R. Abidin, "Population Density and Intensity of Traffic Connection: Spatial Analysis (Overlay)," Int. J. Sci. Res., vol. 7, no. 12, pp. 546-552, 2018.

[23] B. Ko, H. Kim, and J. Nam, "Classification of potential water bodies using Landsat 8 OLI and a combination of two boosted random forest classifiers," Sensors, vol. 15, no. 6, pp. 13763-13777, 2015.

[24] H. Jiang, M. Feng, Y. Zhu, N. Lu, J. Huang, and T. Xiao, “An automated method for extracting rivers and lakes from Landsat imagery," Remote Sens., vol. 6, no. 6, pp. 5067-5089, 2014.
[25] G. Sarp and M. Ozcelik, "Water body extraction and change detection using time series: A case study of Lake Burdur, Turkey," $J$. Taibah Univ. Sci., vol. 11, no. 3, pp. 381-391, 2017.

[26] W. Li and P. Gong, "Continuous monitoring of coastline dynamics in western Florida with a 30-year time series of Landsat imagery," Remote Sens. Environ., vol. 179, pp. 196-209, 2016.

[27] S. K. McFeeters, "The use of the Normalized Difference Water Index (NDWI) in the delineation of open water features," Int. J. Remote Sens., vol. 17, no. 7, pp. 1425-1432, 1996.

[28] G. L. Feyisa, H. Meilby, R. Fensholt, and S. R. Proud, "Automated Water Extraction Index: A new technique for surface water mapping using Landsat imagery," Remote Sens. Environ., vol. 140, pp. 23-35, 2014.

[29] H. Xu, "Modification of normalized difference water index (NDWI) to enhance open water features in remotely sensed imagery," Int. J. Remote Sens., vol. 27, no. 14, pp. 3025-3033, 2006.

[30] R. Maru, N. Nasaruddin, M. Ikhsan, and B. M. Laka, "Perubahan Penggunaan Lahan Kota Makassar Tahun 1990-2010," SAINSMAT" J. Sains, Mat. dan Pembelajarannya, vol. 4, no. 2, pp. 113-125, 2015.

[31] R. Maru and S. Ahmad, "The relationship between temperature patterns and urban morphometry in the Jakarta city, Indonesia," Asian J. Atmos. Environ., vol. 9, no. 2, pp. 101-186, 2015.

[32] R. Maru et al., "Analysis of The Heat Island Phenomenon in Makassar, South Sulawesi, Indonesia," Am. J. Appl. Sci., vol. 12, no. 9, 2015.

[33] R. Maru and S. Ahmad, "The relationship between land use changes and the urban heat island phenomenon in Jakarta, Indonesia," Adv. Sci. Lett., vol. 21, no. 2, pp. 150-152, 2015.

[34] O. Orhan, S. Ekercin, and F. Dadaser-Celik, "Use of Landsat land surface temperature and vegetation indices for monitoring drought in the Salt Lake Basin Area, Turkey," Sci. World J., vol. 2014, 2014.

[35] R. Maru, M. R. Abidin, A. Arfan, S. Nyompa, U. Uca, and S. Hasja, "Mapping of Protected Forests and Cultivated Area in North Luwu South Sulawesi, Indonesia," Asian J. Applied Sci., 2016.

[36] K. Rokni, A. Ahmad, A. Selamat, and S. Hazini, "Water Feature Extraction and Change Detection Using Multitemporal Landsat Imagery," Remote Sens., vol. 6, pp. 4173-4189, 2014.

[37] X. U. Han-Qiu, "A Study on Information Extraction of Water Body with the Modified Normalized Difference Water Index (MNDWI), $J$. Remote Sens., vol. 5, pp. 589-595, 2005.

[38] L. Smith and R. A. Freeze, "Stochastic analysis of steady-state groundwater flow in a bounded domain: 2. Two-dimensional simulations," Water Resour. Res., vol. 15, no. 6, pp. 1543-1559, 1979.

[39] A. Tiwari and B. Rai, "Hydromorphogeological mapping for groundwater prospecting using Landsat-MSS images-a case study of part of Dhanbad District, Bihar," J. Indian Soc. Remote Sens., vol. 24, no. 4, pp. 281-285, 1996.

[40] Y. Du, Y. Zhang, F. Ling, Q. Wang, W. Li, and X. Li, "Water Bodies' Mapping from Sentinel-2 Imagery with Modified Normalized Difference Water Index at 10-m Spatial Resolution Produced by Sharpening the SWIR Band," Remote Sens., vol. 8, no. 354, 2016. 